\title{
A Dispensable Specialist International Environmental Court with Alternative Modest Options
}

Fan Siyuan

School of Art and Law, Wuhan University of Technology, Wuhan, P.R.China,430070 E-mail: 787175498@qq.com

This is an open access article distributed under the Creative Commons Attribution License, which permits unrestricted use, distribution, and reproduction in any medium, provided the original work is properly cited.

\section{ARTICLE DETAILS}

\section{Article History:}

Received 02 october 2017 Accepted 06 october 2017 Available online 11 october 2017

\section{Keywords:}

Specialist environmental court: Limited jurisdiction; Special procedures.

\section{ABSTRACT}

The purpose of this paper is to examine the joint effect of debt financing and credit rating on the corporation's performance. Using a sample of 309 US firm-year observations in the retail industry from year 2011 to 2013, we show that both debt financing and credit rating have positive relationships with corporate performance. Further, when a company has high credit rating, its debt financing ratio has no effect on its performance, while a company with low credit rating; it performs better as debt financing ratio increases. The findings can be applied by CFOs (Chief Finance Officers) in retail companies to build an efficient capital structure when considering the companies' credit ratings. A good combination of these two enables firms to gain a bigger profit and attract more investors.

\section{Introduction}

There are a series of environmental problems that need urgent attention in the world. The difficulties encountered in environmental litigation make it different from many other cases in the International Tribunal for the Law of the Sea or the International Court of Justice. Is it the answer to the creation of a specialist environmental court? Discussions on the advantages and the practicability of a specialist international environmental court regularly (re)surface in debates. Grassroots, environmental organizations take apart in these discussions and legal practitioners supporting the creation of such a tribunal to varying degrees.

Part 2 is about arguments in support of a specialist environmental court. The main arguments are : the existing judicial institution only limited jurisdiction when facing an environmental dispute as a result of the fragmented character of international environmental law.

Part 3 lay out arguments against a specialist environmental court: (a) the first and foremost criticism is that proponents of a specialist court overlook the fact that it is often difficult to discern the "environmental aspects" of a dispute from "non-environmental aspects"; and (b) a specialist environmental court is but one option among many, and there used to be futile attempts of such a court, which, strongly proves that the option receives little support in practice.

Noting that a specialist environmental court is but one option among many,

part 4 gives other modest options for international environmental litigation. Those alternative modest options include: (a) establishing comprehensive jurisdiction over environmental disputes by expansively interpreting the applicable law or by making use of the applicable law article of the applicable law, or by an optional clause declaration under ICJ Statute and (b) establishing special procedures for evidence and proof in environmental disputes by using independent expert as assessor to assist the tribunal or court.

Part 5 is conclusion. The author is obviously in favor of more modest options. And in the author's view, a specialist environmental court is a dispensable option.

\section{Arguments for a Specialist International Environmental Court}

Muddling through might be one way to describe the present state of international environmental litigation. And that makes a specialist environmental court meaningful. Proponents of a specialist environmental court argue that: the existing judicial institution only limited jurisdiction when facing

an environmental dispute as a result of the fragmented character of international environmental law.

\subsection{Limited Jurisdiction of Existing Judicial Institution}

When an existing court or tribunal is faced with an international environmental dispute, if any, observers have found that whatever forum is chosen, the jurisdictional issue arises as a result of the fragmented character of international environmental law: every judicial institution de facto only has partial jurisdiction over the dispute if submitted before this very court or tribunal.

International environmental law, which has been widely recognized, is composed of multiple, overlapping, treaties, customary international law, the framework of the interpretation and application of certain principles in line with the international community agreed. The characteristics of fragmentation, a small island countries affected by climate change, for example, may involve relates to climate change treaty, the Kyoto Protocol, the United Nations Convention on the law of the sea, the Convention on biological diversity, the law of state responsibility, due diligence obligations and habits, the precautionary principle, even some law of human rights. Each applicable treaty has its own dispute settlement terms or not at all, which means any one court will have partial jurisdiction over the dispute if the case is submitted before the very court. In the context of the environmental requirements of the jurisdiction of the Mills case is evident in the jurisdiction of the court from the 1975 statute of the Uruguay river. Although the claims relating to river water environmental pollution fall within the scope of the treaty, the court held that it had no jurisdiction over noise or visual pollution, nor did it smell that Argentina claimed to be caused by the paper pulp Mills. These problems are not covered by the law. Whatever their merits, the court cannot consider them unless the parties agree. On this basis, it may not be possible to establish any court or tribunal that can rule all relevant environmental issues. We may be more interested in the application of a mandatory adjudication system to the environmental dispute settlement treaty, which has the power to apply to all relevant treaties, customary law.

3. Arguments against a Specialist International Environmental Court 
The arguments against a specialist environmental court are as follows:

(a) the first and foremost criticism is that proponents of a specialist court overlook the fact that it is often difficult to discern the "environmental aspects" of a dispute from "non-environmental aspects";

(b) a specialist environmental court is but one option among many, and there used to be futile attempts of such a court, which, strongly proves that the option receives little support in practice.

3.1 An Environmental Case can not Cover the Totality of an "Environmental Dispute"

"It's illusory to believe that environmental disputes can be separated into a self-contained category for the purposes of litigation." This radical view to some extent appears right, for we have not seen an exclusive international environmental case thus far. On the contrary, there are ample cases which have the environmental dimensions as well as aspects of other international areas. And it is easy to conclude that an emergence of a specialist environmental court will definitely intensify the long-existing problems like parallel claims, or overlapping claims or forum shopping, which in turn makes the conflicts and inconsistency of judgments or awards more serious.

The Aerial Spraying Case is a nice example to show the encounter of international environmental law and human rights law. However, for the environmental aspect, environmental treaty in issue is not included in this case. Instead, it is recognized that The situation in Ecuador is mainly based on international law relating to transboundary pollution. There is no denying the fact that the problem of the existence of the human rights treaty has left the correct representation of the case in question:

it is regarded as a human rights case? Columbia believes that the law is the 1988 United Nations Convention on narcotic drugs, because aerial spraying is part of the crop eradication program as an anti narcotics. So far, the Convention on narcotic drugs has been recognized as an environmental treaty.

For the mixture of international environment aspect with international trade, there are many WTO disputes of that kind. The past years have witnessed claims arising from trade rules between countries have also raised environmental concerns. Shrimp turtle Case is the best example. In light of this, if a specialist environmental court is built up, in fact we are building up a specialist trade court or a specialist human right court.

\subsection{The Futile Attempts for Such a Court Demonstrates Little Support in Practice}

In the 80s of last century, when an international environmental court called, a panel of experts headed by former Supreme Court justice Amedeo Postliglione met in Rome. In 1992, the basis of the environment, the International Court of Justice (ICEF) is the purpose of the creation of such a court. Then in the same year the statute of the court. In the draft law, it calls for the establishment of an international environmental agency, and through an international treaty, the basic rights of everyone to the environment. The draft law further announced that ice should be established as a permanent body, the responsibility to protect the environment in the name of the international community as a basic human rights. In addition, supporters want the court to decide any environmental disputes involving the state to the international community, as well as any environmental disputes caused by private or public parties, including the state.

And the futility of ICEF's failure is not only in the international environmental law. In1994, a group of international lawyers set up the International Court of environmental arbitration and conciliation (ICEAC) in Mexico. The court has its functions to facilitate the settlement of disputes between the parties through mediation and arbitration to resolve environmental disputes between the parties of the States, a natural or legal person submitted to it. In addition, the court also provides advice on request. However, on the court's website, the majority of the court's decisions are related to advice (usually related to domestic issues), and no state has received a petition for mediation. Another setback is the international environment in which non existing workloads have been abandoned, and the United States is unwilling to recognize the controversial environment for the purpose of international adjudication.

Recently, the appeal of the International Court of environmental protection has been supported by the newly formed international environmental Court (ICE) alliance, which was founded in the United Kingdom as a limited company. Subsequently, the ICE alliance organized a series of seminars and explore the prospects of the International Court of environmental affairs, the advocacy of the International Criminal Court alliance successfully advocated the creation of the experience of the international criminal court. It remains to be seen whether this company works well.

\section{Alternative Modest Options}

Rather than the radical reforms like a specialist environmental court, it seems better to take a more modest change that would make the current ad hoc system a better tool for resolving international environmental disputes. One commentator noted that if the existing international court is not sufficiently sensitive to international environmental law, the most effective way to solve the problem is to make it sensitive. Some changes mentioned below have already taken place or been in prospect. Those alternative modest options include:

(a) establishing comprehensive jurisdiction over environmental disputes by expansively interpreting the applicable law or by making use of the applicable law article of the applicable law, or by an

optional clause declaration under ICJ Statute or the Pact of Bogota;

(b) establishing special procedures for evidence and proof in environmental disputes by using independent expert as assessor to assist the tribunal or court.

4.1 Establishing Comprehensive Jurisdiction over Environmental Disputes

Note should be taken that for the limited jurisdiction it is not an unique question only to the environmental arena. It is a question inherently based on the fragmented character of international law as well as the very jurisdiction requirement of parties' consensus. The answer is not a specialist environmental court, however. What really matters is the extent to the mandate or capacity of existing judicial institutions or to the so called specialist environmental court is successfully set up. We have seen the failure both of the International Court of Environmental Arbitration and Conciliation (ICEAC) and environmental chamber of the ICJ. Thus it is the actors of international law that should play a vital role. Since it is difficult to reconcile the interests of present actors, it remains the better way to find ways to make the existing judicial institutions work better.

Thus here is not the place to discuss the incentives for international actors to promote international environmental law. Rather, as the time is not ripe for a new court with comprehensive jurisdiction, it seems better to try to avoid the limited jurisdiction within the existing regimes by some approaches. The limited jurisdiction does not mean that the judgment is only relevant to the specific issues arising under a bilateral instrument binding on only two states. The court in issue can interpret the applicable law in a progressive way. So judges and arbitrators have taken a conservative attitude towards this approach by only reading into the applicable law generally recognized international environmental law, inter alia customary international environmental law and general principles.

\subsection{Using Independent Expert as Assessor to Assist the Tribunal or Court}

Scientific and technology play a very important role in the environmental cases. One of the dangers of relying on party-appointed experts is that examination and interrogations can create further doubts about the evidence. If the experts present their views as advisers,the problem well become more difficult in the case that they are not subject to cross-examination.So their advise lack credibility. In the case of pulp mill, the International Court of Justice expressed concern that the use of counsel by experts was that the persons who provided evidence to the court in accordance with the scientific and technical knowledge and personal experience of the court should testify as witnesses.

The advantages of using Independent expert is obvious. The experts are able to provide the court with other important evidence of the fact otherwise within the territorial control of the respondent state. This situation which will representative many environmental cases. In this situation, the experts can visit the relevant locations and are able to provide evidence the applicant state can not lawfully obtain. 
There are also dangers in this approach, though independent experts may be able to help courts and tribunals to perform their fact-finding functions. Because a court rely on their own risks, the decision will be handed over to these experts. The use of an independent expert may also alter the nature of the proceedings, from the fact that one party bears the responsibility of proving the facts of the claim to the adversarial contest to the court or the court on the establishment of the proceedings of the investigation.

Therefore, the appointment of experts as jurors, and the court may be considered more sensible. In the "kissane Gaga award part Award" in 2013 in PCA, one of the seven arbitrator is appointed as a scientist, he is directly related to the professional knowledge in hydrology. Everyone else is an international lawyer.

\section{Conclusion}

It is recognized that there are problems after examining the current international environmental litigation. Environmental activists have been constantly calling for the creation of a specialist international environmental court but these propositions receive little support from academic writing.Even if we might like to set up such a court, before it succeeds there need to be a political matter, for negotiation, not one straight for courts, however creative.

Rather than go down this above route, We believe that the current system can resolve the problems. And the more modest changes that make the current ad hoc system a better tool to solve environmental disputes.

\section{References}

[1] Alan Boyle and James Harrison.Judicial Settlement of International Environmental Disputes: Current Problems.[J].Journal of International Dispute Settlement,Vol.4,No.2(2013).pp245-276.

[2] Philippe Sands.Litigating Environmental Disputes: Courts, Tribunals And the Progressive Development of international Environmental Law[J].Global Forum on International Investment VII.2008-03.

[3] Dionysia.The Role of the International Judiciary in the Settlement of Environmental Disputes and Alternative Proposals for Strengthening International Environmental Adjudication[J].Yale Center for Environmental Law and Policy.2003-10.

[4] Stephen Hockman.The Case for an International Court for the Environment[J].the Effectius Newsletter, Issue 14, (2011).

[5] Olew Pedersen.An International Environmental Court and International LegalismJournal of Environmental Law.Oxford University Press.2012-10-15.

[6] Bharat $\mathrm{H} \bullet$ Desai and Balraj Sidhu.International Environmental Dispute Settlement-Rio+20 and Beyond-[J].Environmental Policy and Law. 42/2 (2012).

[7] ICE Coalition.Environmental Institutions for the 21st Century: An International Court for the Environment[J].SDG2012.2011-02 